SINAI Journal of Applied Sciences 10 (2) $2021 \quad 107-120$

\begin{tabular}{ccc}
\multicolumn{4}{c}{ Available online at www.sinjas.journals.ekb.eg } \\
SCREENED BY SINAI Journal of Applied Sciences
\end{tabular}

\title{
IMPACT OF FEEDING OF BIO-YOGHURT FORTIFIED WITH GLYCOMACROPEPTIDE AND CRUDE VIRGIN OLIVE OIL ON BIOLOGICAL ACTIVITIES OF RATS
}

\author{
Ola F. El-Sayed $^{* 1}$, H.A. El-Shazly ${ }^{2}$, H.A. El-Demerdash ${ }^{1}$, M.M.K. Metwally ${ }^{1}$ \\ 1. Dept. Dairy and Food Sci., Fac. Environ. Agric. Sci., Arish Univ., Egypt. \\ 2. Dept. Dairy Sci., Food Technol. Res. Inst., Ministry Agric. and Land Reclamation, Egypt.
}

\begin{tabular}{l} 
ARTICLE INFO \\
\hline Article history: \\
Received: $20 / 06 / 2021$ \\
Revised: 28/08/2021 \\
Accepted: $28 / 08 / 2021$ \\
Available online: $28 / 08 / 2021$ \\
\hline Keywords: \\
Yoghurt, B. bifidum, \\
GMP, \\
olive oil
\end{tabular}

\begin{abstract}
The biological effects of bio-yoghurt fortified with glycomacropeptide (GMP) and crude virgin olive oil (CVOO) and Bifidobacterium bifidum Bb12 were investigated on rats. The rats were fed on basal diet and experimental diet in appropriate amounts of basal diet and yoghurt in the ratio 1:1 (W/W) and fresh water were supplied with meal for 21 days compared to control (-) which fed on basal diet only. Rats were arranged in 4 groups, 5 rats each. The results revealed no significant differences between rats' initial body weight whereas a significantly different $(\mathrm{p}<0.05)$ between rats' final body weight and body weight gain and there is a relative difference in liver, spleen, kidney and heart weights between treated groups and control (-) group (IV), moreover histopathological examination of rats liver tissues indicated the healthful effect of feeding on yoghurt fortified with GMP,CVOO and B. bifidum compared to control ( - ), also all groups fed on yoghurt fortified with GMP,CVOO and B. bifidum showed ahipolipidemic action demonstrated by a significant reduction in the concentration of plasma cholesterol, triglycerides and phospholipids and tended to lower plasma low density lipoprotien (LDL) cholesterol concentration and leading to lowering liver enzymes; glutamicpyruvic transaminase (GPT) and glutamic-oxaloacetic transaminase (GOT), moreover the rats fed on yoghurt fortified with food additives and B. bifidum had higher counts of lactic acid bacteria and B. bifidum, and lower counts of staphylococci and coliforms.
\end{abstract}

\section{INTRODUCTION}

Yoghurt is a coagulated dairy product produced by fermentation of milk with bacterial cultures consisting of a mixture of Streptococcus thermophilus and Lactobacillus delbrueckii subsp. bulgaricus (Gundogdu, et al. 2009). Addition of these cultures results in acidification of milk and synthesis of aromatic compounds (Sahan et al., 2008; Sera et al., 2009). These microflorae have been found to be valuable for human as they help in maintaining health and nutrition. Efforts have been focused on developing yoghurt containing probiotic cultures like Lactobacillus acidophilus and Bifidobacterium bifidum (Vinderola and
Reinheimer, 2000).Probiotic cultures are live microbial food ingredients that are beneficial for human health and improve the intestinal microbial balance resulting in the inhibition of bacterial pathogens, reducing the risk of colon cancer, improving the immune system, lowering serum cholesterol levels (Saarela et al., 2002) and alleviation of lactose intolerance and nutritional enhancement (Alizadeh and Ehsani, 2008).

Glycomacropeptide (GMP), arising from cleavage of $\kappa$-casein by chymosin or pepsin (Farrell et al., 2004), exhibits several useful biological activities, including binding of cholera toxin and E. coli enterotoxins,

\footnotetext{
* Corresponding author: E-mail address: ommoaaz50@gmail.com https://doi.org/10.21608/sinjas.2021.79960.1025

(C) 2021 SINAI Journal of Applied Sciences. Published by Fac. Environ. Agric. Sci., Arish Univ. All rights reserved.
} 
inhibition of bacterial and viral adhesions, suppression of gastric secretions, promotion of bifidobacterial growth, and modulation of immune responses (Brody, 2000). GMP contains nonaromatic amino acids and is therefore used for phenylketonuria (PKU) diets (Ney et al., 2009). It is growing interest in exploiting GMP for use in the food industry, GMP provides good palatability and functional properties imparting favorable mouthfeel and flavour to foods, which many existing food preparations used for PKU diets lack (Marshall, 2004).

Olive (Olea europea L.) is an evergreen tree that has been traditionally cultivated for olive oil and table consumption. Olive oil is classified as virgin olive oil if it has been extracted exclusively by mechanical or physical procedures such as milling, beating, centrifugation and decantation (Gandul-Rojas et al., 2000). The importance of virgin olive oil is related to its high levels of mono-unsaturated fatty acids (mainly oleic acid) and to the presence of minor components including aliphatic and tri-terpenic alcohols, sterols, hydrocarbons, volatile compounds and several antioxidants (Ocakoglu et al., 2009). Olive oil is rich diet protects human health from cardiovascular diseases, hypertention, inflammation, oxidative stress, obesity, type-2 diabetes and cancer (Wani et al., 2018).

\section{MATERIALS AND METHODS}

\section{Materials}

Fresh cow's milk was obtained from the herd of Badwy farm of Arish, Egypt. Average chemical composition of milk (3.5\% fat, $3.35 \%$ protein, $12.6 \%$ TS) were determined according to the methods described in AOAC (2016).

Skim milk powder $(96 \% \mathrm{TS}$, product of Dairy America $^{\mathrm{TM}}$ ) USA, was obtained from the local market of Arish, Egypt.
Direct Vat Starter (DVS) of yoghurt culture was obtained from CHR-Hansen's laboratorie, Denmark, under commercial name type (FD-DVS-YC-X11) containing Streptococcus thermophiles and Lactobacillus delbrueckii ssp. Bulgaricus.

Probiotic bacteria strain Bifidobacterium bifidum Bb12 was obtained from bafm, Germany.

Glycomacropeptide (GMP) was obtained from Ajinomoto Co., Inc.,Tokyo, Japan.

Crude virgin olive oil (CVOO) (Olea europea L.) was obtained from Badawy olive press of Arish, Egypt.

\section{Methods}

\section{Preparation of probiotic culture}

Strains of Bifidobacterium bifidum was twice successively activated by inoculating $100 \mathrm{ul}$ of organism in $10 \mathrm{ml}$ of sterilized MRS broth and incubated at $37^{\circ} \mathrm{C}$ for 16 hours. $10 \mathrm{ml}$ of inoculated MRS broth was added to $100 \mathrm{ml}$ of skim milk (9\%) and incubated at $37^{\circ} \mathrm{C}$ over night, then stored at $5^{\circ} \mathrm{C}$ until used according to De Man et al. (1960).

Yoghurt was manufactured from standardized cow's milk according to Tamime and Robinson, (1999). Three treatments of yoghurt were prepared as follows:

\section{Treatment 0 (T0)}

Yoghurt without any additives which serves as a control is shown in Diagram A.

\section{Treatment 1 (T1)}

Yoghurt with $0.01 \%$ GMP was used in manufacture of yoghurt according to the procedure mentioned by Tain et al. (2015) is shown in Diagram A.

\section{Treatment 2 (T2)}

Yoghurt with $0.1 \%$ crude virgin olive oil was used in the manufacture of yoghurt according to the procedure mentioned by Abbas et al. (2015) is shown in Diagram A. 
Diagram (A) - Manufacture of yoghurt

Fresh cow's milk (3.5\% fat, $3.35 \%$ protein, $12.6 \%$ T.S)

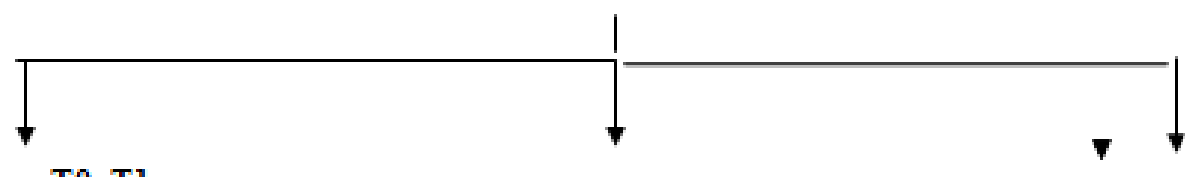

T0, Tl<smiles>C[13CH3]</smiles>

Addition of $3 \%$ skimmilkpowder

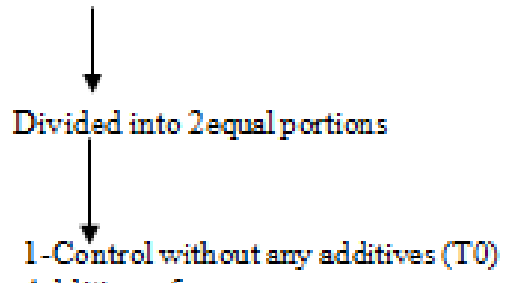

Addition of

\section{$2-0.01 \% \mathrm{GMP}(\mathrm{T} 1)$}

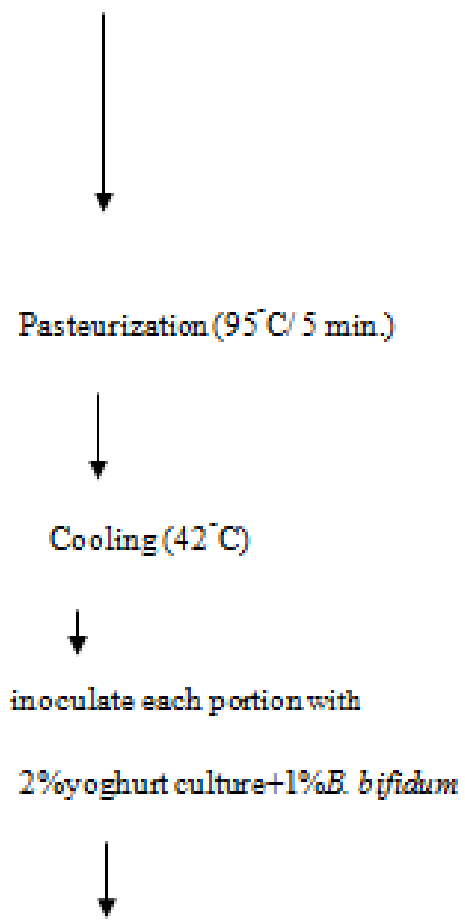

Filled into plastic

container

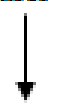

Incubation at $42^{\circ} \mathrm{C}$ until complete coagulation

Storage in refifgerator at $5^{\circ} \mathrm{C}$ for 21 days
$\mathrm{T} 2$

Addition 3\% skimmill powder

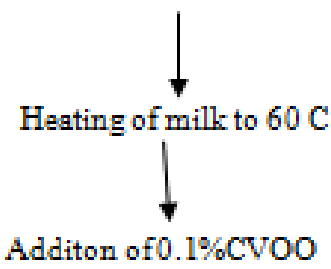

$\downarrow$

Mixing the mixture in a blender

Reheating of mix. for Pasteurization

$\left(95^{\circ} \mathrm{C} / 5 \mathrm{~min}\right)$

Cooling $\left(42^{\circ} \mathrm{C}\right)$

Inoculation with $2 \%$ yoghurt culture $+1 \%$ B. bfidum

Filled into plastic containers

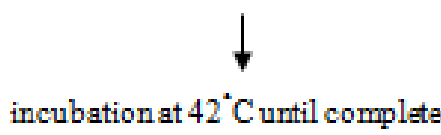

coagulation

Storage in refrigerator at $5^{\circ} \mathrm{C}$ for 21 days 


\section{Animals and diets}

Four weeks old Albino rats with average weighing between (100-130 g) were purchased from Modern Animal Care Center, National Research Center, Giza, Egypt. The rats were housed individually in an air conditioned room at $21-24^{\circ} \mathrm{C}$ with $12 \mathrm{~h}$ - light/12 hr dark cycle. The rats were acclimatized on commercial basal diet (Cairo poultry Company,Giza, Egypt) for one week before starting the experiment . The chemical composition of basal diet was as following: $20 \%$ casein, $10 \%$ safflower oil, 5\% vitamins and salt mixture, 5\% cellulose, $15 \% \quad \alpha$-corn starch, and $45 \%$ sucrose). The rats fed on basal diet and experimental diet and fresh water were supplied with meal for 21 days and the rats' body weight was measured in the beginning and the end of the experimental period.

\section{Experimental Design}

The rats were arranged in 4 groups, 5 rats each. Except for the control (-) diet, all diets were adjusted to contain appropriate amounts of basal diet and yoghurt in the ratio 1:1. The rats' groups were as the following:

Group I: (control +) rats fed on basal diet and yoghurt with mixed culture of (St. thermophiles, Lb. delbrueckii ssp. bulgaricus and $B$. bifidum), without any additives.

Group II: rats fed on basal diet and yoghurt fortified with $0.01 \%$ GMP and mixed culture of (St. thermophiles, Lb. delbrueckii ssp. bulgaricus and B. bifidum).

Group III: rats fed on basal diet and yoghurt fortified with $0.1 \%$ CVOO and mixed culture of (St. thermophiles, $L b$. delbrueckii ssp. bulgaricus and B. bifidum).

Group IV: (Control -) rats fed on basal diet only.

\section{Tissue sampling and analysis}

At the end of the experiment rats were anesthetized with diethyl ether. Blood of each rat was collected by capillary tubes and centrifuged at $3000 \mathrm{rpm}$ for $15 \mathrm{~min}$ to separate plasma and red blood cells (RBCs). The erythrocyte lysates $(20 \% \mathrm{~V} / \mathrm{V})$ were prepared by lying aliquots of washed RBCs with deionized water as described by Huang and Fwu (1992). Rats' spleen, liver, kidney and heart were removed, washed by physiological saline, dried over filter papers and their weights were recorded. All samples were kept under freezing until analysis.

\section{Histopathological Examination}

At the end of the experiment, the lobe of Liver tissues was carefully dissected out, and then fixed instantaneously in $10 \%$ formal saline for $24 \mathrm{hr}$. The specimens were washed in tap water, dehydrated in ascending grades of ethanol, cleared in xylene, embedded in paraffin wax (melting point $55-60^{\circ} \mathrm{C}$ ). Sections of $5 \mu \mathrm{m}$ thicknesses were prepared and stained with Haematoxylin and Eosin. The cytoplasmstained shade of pink and red and the nuclei gave blue color (Sturgill and Lambert, 1997). Examined by National Research Center, Giza, Egypt.

\section{Determination of liver enzymes}

GPT and GOT were determined enzymatically by kits from Medical Device Safety Services (MDSS GmbH), Burckhardtstr.1, 30163 Hannover, Germany.

\section{Determination of plasma lipid}

Total cholesterol, high density lipoprotein (HDL) cholesterol, low density lipoprotein (LDL) cholesterol, triglyceride ad phospholipids were determined ezymatically by kits from Medical Device Safety Services (MDSS GmbH), Burckhardtstr.1, 30163 Hannover, Germany.

\section{Microbiological analysis of feces of rats}

Fecal samples were collected from rectum in a sterilized Petri dish and $1.0 \mathrm{~g}$ of feces was transferred to $99 \mathrm{ml}$ saline. Samples were analyzed immediately using aseptic sterile dilution technique as described by Patel $\boldsymbol{e t}$ al. (1992), in National Research Center. 
Determination of Lb.bulgaricus and St. thermopiles count

Fecal Lb. bulgaricus and St. thermopiles were enumerated on bromocresol green whey agar medium. Plates were incubated at $43 \mathrm{C}$ for $48 \mathrm{hr}$ according to Yamani and Ibrahim, (1996).

\section{Determination of Bifidobacteria count}

Fecal Bifidobacteria was enumerated on MRS agar medium. Colonies were counted after anaerobic incubation using a double layer of medium. Plates were incubated at $37^{\circ} \mathrm{C}$ for $48 \mathrm{hr}$ according to Dave and Shah (1996).

\section{Determination of coliform bacterial counts}

Appropriate dilutions of fecal samples were plated on MacConky's agar medium. After solidification, plates were incubated at $37^{\circ} \mathrm{C}$ for $48 \mathrm{hr}$, the bacterial count was expressed as cfu of coliform /g of fecal as described by American Public Health Association, (1992).

\section{Determination of staphylococci bacterial count}

The counts of staphylococci were determined on Staph 110 media, incubated at $37^{\circ} \mathrm{C}$ for $48 \mathrm{hr}$ as described by American Public Health Association (1992).

\section{Statistical Analysis}

The statistical analysis was carried out using one-way analysis of variance (ANOVA) under significant level of 0.05 for the whole results using the statistical program Costas (Ver. 6.400) and data were expressed as mean \pm stander error (SE) with complete randomization design according to Steel et al. (1997). To ascertain the significant among means of different samples, least significant difference (LSD) test was applied.

\section{RESULTS AND DISCUSSION}

\section{Rats' Growth Properties}

Tables 1 and 2 illustrate the effect of feeding on yoghurt fortified with GMP,
CVOO and $B$. bifidum of rats' growth parameters after 21 days of feeding.

It is clear from these tables that, there were no significant differences among rats' initial body weight whereas a significant different $(\mathrm{p}<0.05)$ between rats' final body weight and body weight gain (final body weight - initial body weight) was noted and increased in all rats fed on bio-yoghurt fortified with GMP, CVOO and B. bifidum compared to control (+) group (I) and control (-) group (IV) also control (+) group (I) had body weight gain more than control (-) group (IV).

There is a positive correlation between the animal body weight and its organs especially, liver, spleen, kidney and heart (Michael et al., 2007). In this respect, results in Table 2 illustrate relative difference in liver, spleen, kidney and heart weights between treated groups and control (-) group (IV).

These results are in agreement with those obtained by Hargove and Alford (1978), they reported that rats fed yoghurt gained weight faster than those fed unfermented milk.

\section{Histopathology Results}

It is clear from the following figures 1:8 Histopathological examination of rats' liver tissues indicated a beneficial physiological effect and possible protective role of feeding on bio-yoghurt fortified with GMP, $\mathrm{CVOO}$ and $B$. bifidum on liver tissues damage compared to the control (-) group. Liver is one of the most important vital organs and responsible for many metabolic functions (Sturgill and Lambert, 1997). These findings agreed with (Hualin wanga et al., 2014) who findings that olive oil had great protective effect on liver tissue.

\section{Concentrations of plasma lipids of rats}

Table 3 illustrate the effect of fed on bioyoghurt fortified with GMP, CVOO and $B$. Bifidum on concentrations of plasma lipids 
Table 1. Body weight gain of rats fed on bio-yoghurt fortified with GMP and CVOO

\begin{tabular}{lcccccc}
\hline $\begin{array}{c}\text { Body weight } \\
\text { (g) }\end{array}$ & \multicolumn{6}{c}{ Groups } \\
\cline { 2 - 3 } \cline { 5 - 7 } Initial & I & II & & III & IV & LSD 0.05\% \\
Final & $107.35^{\mathrm{a}} \pm 6.6$ & $110.0^{\mathrm{a}} \pm 7.0$ & & $114.0^{\mathrm{a}} \pm 7.0$ & $112.0^{\mathrm{a}} \pm 3.0$ & 22.49 \\
Gain & $135.0^{\mathrm{a}} \pm 8.0$ & $149.5^{\mathrm{a}} \pm 10.5$ & & $160.2^{\mathrm{a}} \pm 15.9$ & $130.0^{\mathrm{b}} \pm 5.0$ & 41.26 \\
\hline
\end{tabular}

Group I: (Control +) Rats fed on bio-yoghurt without any additives + basal diet.

Group II: Rats fed on bio-yoghurt fortified with $0.01 \%$ GMP + basal diet.

Group III: Rats fed on bio-yoghurt fortified with $0.1 \%$ CVOO + basal diet.

Group IV: (Control -) Rats fed on basal diet. Values are means \pm SE for 5 rats per group.

Means, in the same row with different letters are significantly different $(\mathrm{p}<0.05)$.

Table 2. Growth parameters of rats fed on bio-yoghurt fortified with GMP and CVOO

\begin{tabular}{lcccccc}
\hline $\begin{array}{l}\text { Growth parameter } \\
\text { (g/100g body weight) }\end{array}$ & I & II & & Groups & III & LSD 0.05\% \\
\cline { 2 - 3 } Liver (\%) & $3.36^{\mathrm{a}} \pm 0.39$ & $3.53^{\mathrm{a}} \pm 0.44$ & & $3.70^{\mathrm{a}} \pm 0.46$ & $3.30^{\mathrm{a}} \pm 0.36$ & 1.49 \\
Spleen (\%) & $0.29^{\mathrm{a}} \pm 0.04$ & $0.34^{\mathrm{a}} \pm 0.04$ & & $0.38^{\mathrm{a}} \pm 0.03$ & $0.28^{\mathrm{b}} \pm 0.03$ & 0.11 \\
Kideny (\%) & $0.70^{\mathrm{a}} \pm 0.03$ & $0.75^{\mathrm{a}} \pm 0.04$ & & $0.80^{\mathrm{a}} \pm 0.04$ & $0.68^{\mathrm{b}} \pm 0.03$ & 0.12 \\
Heart (\%) & $0.35^{\mathrm{a}} \pm 0.03$ & $0.38^{\mathrm{a}} \pm 0.03$ & & $0.41^{\mathrm{a}} \pm 0.03$ & $0.34^{\mathrm{a}} \pm 0.04$ & 0.11 \\
\hline
\end{tabular}

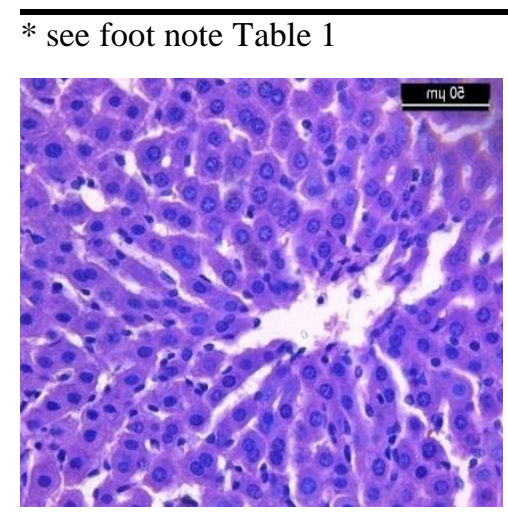

Fig. 1. Hepatic lobule (group I)

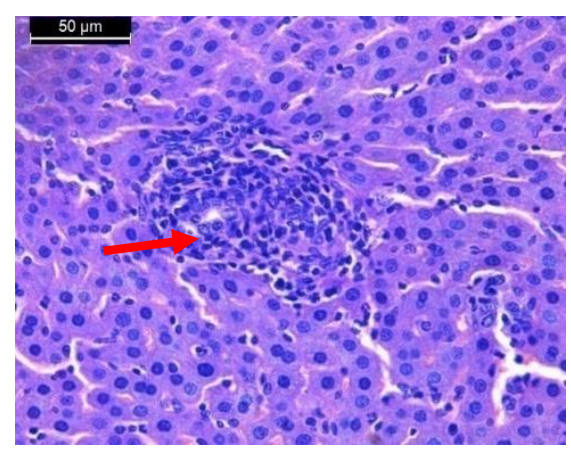

Fig. 2. Portal area (group I)

Light micrograph of a liver section from rats' group I (control +) supplemented with bioyoghurt without any additives and basal diet showing normal structure of the hepatic lobule and moderate inflammation around the portal area.

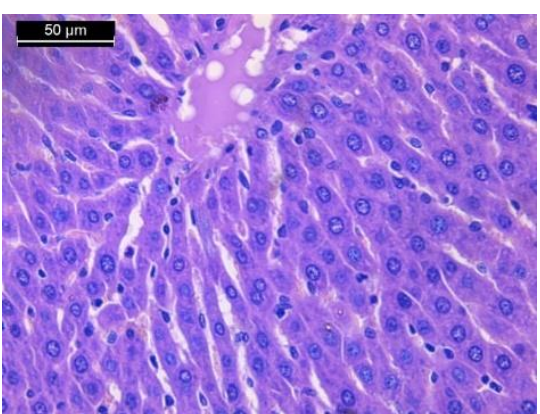

Fig. 3. Hepatic lobule (group II)

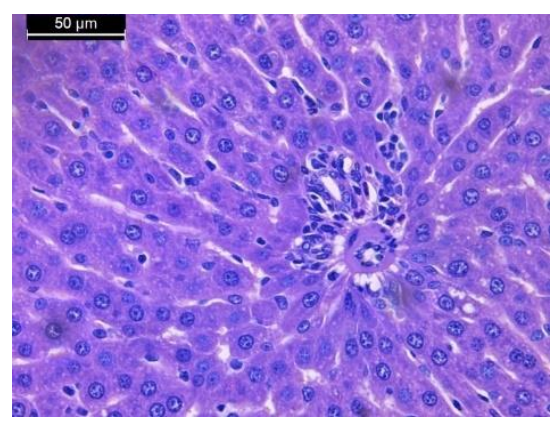

Fig. 4. Portal area (group II)Light

micrograph of a liver section from rats (group II) fed on bio-yoghurt fortified with $0.01 \%$ GMP and basal diet showing the hepatic lobule appeared nearly normal structure and normal structure of the portal area appeared nearly normal structure. 


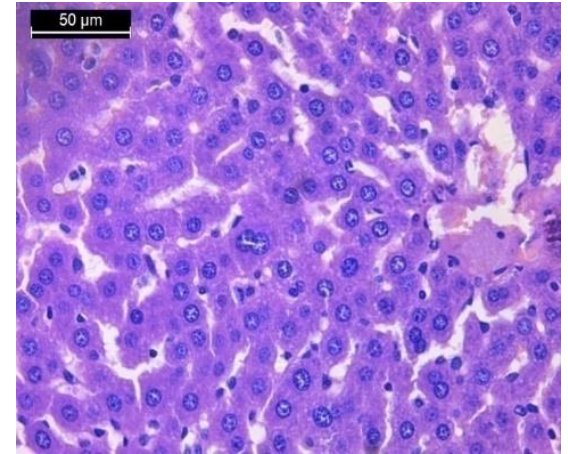

Fig. 5. Hepatic lobule (group III)

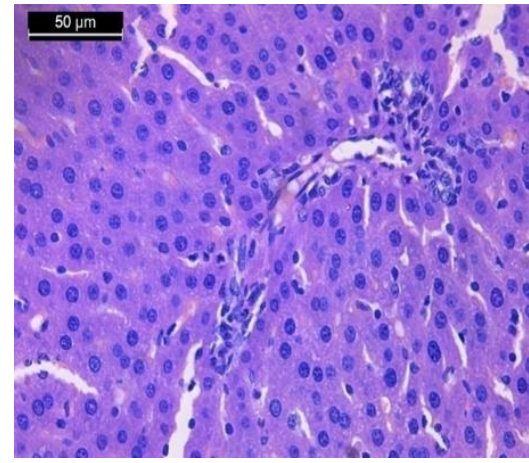

Fig. 6. Portal area (group III)

Light micrograph of a liver section from rats (group III) supplemented with bio-yoghurt fortified with $0.1 \%$ crude virgin olive oil and basal diet showing normal structure of the hepatic lobule and portal area.

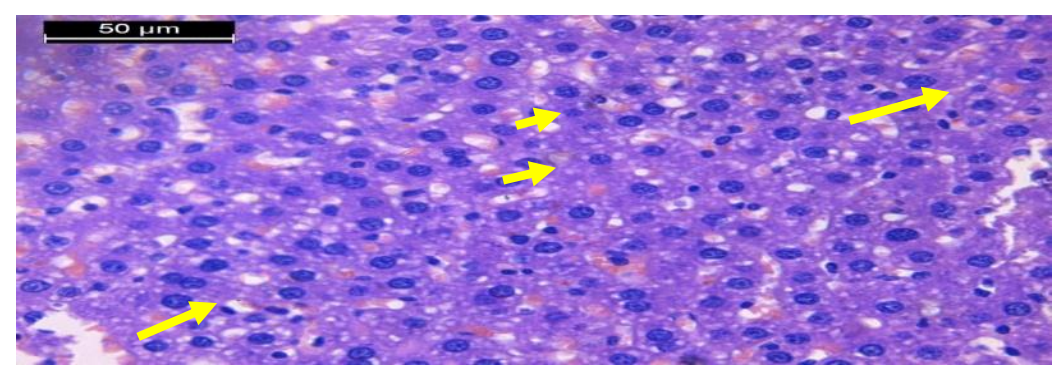

Fig. (7) Hepatic lobule (group IV) Light micrograph of a liver section from rat from (control -) rat group (IV) that fed basal diet only showing disturbance hepatic lobule. Notice a macrovesicular (arrows) and microvesicular (arrowheads) pattern of fatty infiltration.

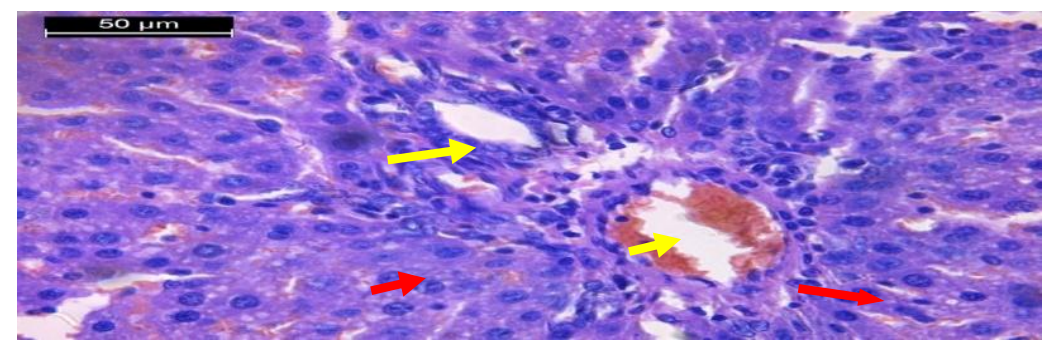

Fig. (8) Portal area (group IV) Light micrographs of liver of a section of liver from (control -) rat group (IV) that fed basal diet only congested portal area that associated with lymphocytic infiltration (arrow) in the portal and periportal areas (arrow). Notice the dilated sinusoids (arrowhead). Some nuclei showed hyperchromasia (red arrowhead) and other showed pyknosis (red arrow).

Table 3. Concentration of serum lipids of rats fed on bio-yoghurt fortified with GMP and CVOO

\begin{tabular}{lccccccc}
\hline $\begin{array}{l}\text { Parameter } \\
(\mathbf{m g} / \text { dl })\end{array}$ & \multicolumn{6}{c}{ Groups } \\
\cline { 2 - 3 } \cline { 6 - 8 } & I & II & III & IV & LSD 0.05\% \\
\hline Cholesterol & $90.2^{\mathrm{a}} \pm 9.8$ & $85.15^{\mathrm{ab}} \pm 05.15$ & & $78.0^{\mathrm{b}} \pm 9.4$ & $98.25^{\mathrm{a}} \pm 4.75$ & 1.49 \\
Triglycerides & $70.0^{\mathrm{a}} \pm 12.0$ & $62.5^{\mathrm{ab}} \pm 14.5$ & & $45.0^{\mathrm{b}} \pm 6.0$ & $74.0^{\mathrm{a}} \pm 13.0$ & 0.11 \\
Phospholipids & $146.0^{\mathrm{ab}} \pm 6.0$ & $141.0^{\mathrm{ab}} \pm 6.0$ & & $118.8^{\mathrm{b}} \pm 19.2$ & $153.5^{\mathrm{a}} \pm 3.5$ & 0.12 \\
\hline
\end{tabular}

* see foot note Table 1 
of rats. It is clear from this table that all groups fed on bio-yoghurt fortified with GMP, CVOO and B. bifidum showed ahipolipidemic action demonstrated by a significant reduction in the concentration of plasma cholesterol, triglycerides and phospholipids more than control (+) group (I) and control (-) group (IV) and all results was in the normal range. The highest value of plasma lipids was recorded in each of control (-) group (IV) while the lowest values recorded in group (III) fed on bio-yoghurt fortified with CVOO and this might be attributed to its high content of polyphenols which act as antioxidants and had role in reducing cholesterol (Estruch et al., 2013). These results are in agreement with those obtained by Kheadr et al. (2000) they demonstrated the hypocholesterolemic effect of yoghurt culture in human and laboratory animals.

\section{Concentrations of Serum HDL and LDL Lipoprotein Cholesterol of Rats}

Table 4 shows plasma lipoprotein (HDL, LDL) concentration and atherogenic indices of rats fed on bio-yoghurt fortified with GMP, CVOO and B. bifidum and it was clear that, all groups fed on bio-yoghurt fortified with GMP, CVOO and B. bifidum tended to lower plasma LDL cholesterol concentration which had harmfull effects in the health more than control (-) group (IV). Results showed no significant differences in HDL cholesterol among all rats' groups and all results were in the normal range. The highest value of HDL-cholesterol was recorded in group (II) fed on GMP while, the lowest was recorded in control (+) group (I). Whereas there were a significant different $(p<0.05)$ among groups in LDL cholesterol and the highest value was recorded in each of control (-) group (IV) followed by control (+) group (I) while the lowest value was recorded in group (III) fed on CVOO. This reduction may be attributed to the reduction of total cholesterol (Kheadr et al. (2000). Also, there were significant differences $(\mathrm{p}<0.05)$ among groups in the ratio of HDL cholesterol to total cholesterol and the highest value was recorded in group (III) fed on CVOO while, the lowest value was recorded in control (-) group (IV). LDL cholesterol to total cholesterol (the atherogenic index) is an indication for susceptibility for atherosclerosis (Kawase $\boldsymbol{e t}$ al., 2000) was comparable among all groups and the highest value was recorded in control (-) group (IV) followed by control (+) group (I) while the lowest value was recorded in group (III) fed on CVOO and this might be attributed to its high content of phenolic compounds display a broad spectrum of health promoting characteristics, including lipid-improving, anti-oxidant, antiinflammatory, anti-atherogenic, antithrombotic, anti-mutagenic, anti-microbial effects (Gorzynik et al., 2018).

\section{Activity of Liver Enzymes (GOT, GPT) in Rats' Serum}

Table 5 show activity of GOT and GPT in rats serum fed on bio-yoghurt fortified with GMP, CVOO and B. bifidum resulted in lower activity of these enzymes compared to control (-) group (IV) that were in the normal range. GPT was found in significant quantities in liver, kidney and skeletal muscle, in decreasing order when liver cells are damaged, GOT and GPT levels rise especially early in the disease (Othman and El-Missiry, 1998). These results may suggest a beneficial physiological effect and possible protective role of feeding rats on bio-yoghurt fortified with GMP, CVOO and B. bifidum. There is significant different $(\mathrm{p}<0.05)$ among groups and the highest value was recorded in control (-) group (IV) followed by control (+) group (I) whereas the lowest value was recorded in group (III) fed on yoghurt fortified with CVOO. These results are in agreement with those obtained by Caramia et al. (2012). 
Table 4. Concentration of serum HDL and LDL lipoprotein cholesterol and atherogenic indices of rats fed on bio-yoghurt fortified with GMP and CVOO

\begin{tabular}{|c|c|c|c|c|c|}
\hline \multirow{2}{*}{$\begin{array}{c}\text { Parameter } \\
\text { (mg/dl) }\end{array}$} & \multicolumn{5}{|c|}{ Groups } \\
\hline & I & II & III & IV & LSD 0.05\% \\
\hline$\overline{\text { HDL Cholesterol }}$ & $65.1^{\mathrm{a}} \pm 1.3$ & $71.8^{a} \pm 10.4$ & $70.2^{\mathrm{a}} \pm 9.6$ & $69.2^{\mathrm{a}} \pm 9.8$ & 31.88 \\
\hline LDL Cholesterol & $24.6^{\mathrm{ab}} \pm 7.2$ & $11.0^{\mathrm{ab}} \pm 4.2$ & $7.5^{\mathrm{b}} \pm 4.1$ & $29.2^{\mathrm{a}} \pm 5.0$ & 18.75 \\
\hline HDL/Total cholesterol & $0.73^{\mathrm{b}} \pm 0.06$ & $0.84^{\mathrm{ab}} \pm 0.07$ & $0.90^{\mathrm{a}} \pm 0.02$ & $0.69^{c} \pm 0.07$ & 0.18 \\
\hline Atherogenic index & $0.26^{\mathrm{ab}} \pm 0.05$ & $0.12^{\mathrm{b}} \pm 0.04$ & $0.09^{b} \pm 0.04$ & $.30^{\mathrm{a}} \pm 0.07$ & 0.17 \\
\hline
\end{tabular}

* see foot note Table 1

Table 5. Activity of liver enzymes (GOT and GPT) in serum of rats fed on bio-yogurt fortified with GMP and CVOO

\begin{tabular}{ccccccc}
\hline \multirow{2}{*}{$\begin{array}{c}\text { Parameters } \\
\text { (U/d) })\end{array}$} & \multicolumn{5}{c}{ Groups } \\
\cline { 2 - 3 } GOT & $76.2^{\mathrm{ab}} \pm 11.6$ & $67.6^{\mathrm{b}} \pm 11.2$ & & $53.3^{\mathrm{b}} \pm 7.4$ & $103.8^{\mathrm{a}} \pm 9.6$ & 35.46 \\
GPT & $16.1^{\mathrm{ab}} \pm 1.4$ & $14.6^{\mathrm{b}} \pm 0.8$ & & $12.7^{\mathrm{b}} \pm 0.9$ & $24.6^{\mathrm{a}} \pm 2.2$ & 4.38
\end{tabular}

* see foot note Table $1 *$ GOT: glutamic-oxaloacetic transaminase. *GPT: glutamic-pyruvic transaminase.

Effect of Fed on Bio-Yoghurt Fortified with GMP and CVOO on Fecal Bacterial Population of Rats

Table 6 illustrate the effect of fed on bioyoghurt fortified with GMP, CVOO and $B$. bifidum on fecal bacterial population of rats. The results indicated that, there were considerable variations among rat groups in their fecal content of LAB, B. bifidum, staphylococci and coliforms. The rats fed on bio-yoghurt fortified with GMP, CVOO and $B$. bifidum had higher counts of LAB and $B$. bifidum, On the other hand the number of staphylococci and coliforms bacterial counts significantly reduced in the feces of these groups compared to control (-) group. The highest count for each of LAB and B. bifidum was recorded in group (II) fed on bio-yoghurt fortified with GMP followed by group (III) fed on bio-yoghurt fortified with CVOO, while the lowest count was recorded in control (-) group
(IV). The highest count for each of staphylococci and coliforms bacteria was recorded in control (-) group (IV) whereas, the lowest count was recorded in each of group (II) and group (III). These results are in agreement with those obtained by Misra and Kulla (1994) who found that dietetic yoghurt supplemented with $B$. bifidum creates favorable conditions for proliferation of beneficial intestinal microorganisms and discourage the growth of harmful ones. Also, GMP enhances the establishment of a healthy intestinal microbiota and prevents pathogenic bacteria colonization in mice after 15 days of daily treatment with GMP and using fluorescence in situ hybridization, a significant increasment in each of the number of Lactobacillus and Bifidobacteria was observed, together with a significant decrease in Enterobacteriaceae and coliforms on fecal samples of mice (Chen et al., 2012). 
Table 6. Effect of fed on bio-yoghurt fortified with GMP and CVOO on fecal bacterial population of rats

\begin{tabular}{lcccccc}
\hline Parameters & \multicolumn{5}{c}{ Groups } \\
\cline { 2 - 3 }$(\log$ cfu/g) & I & II & & III & IV & LSD 0.05\% \\
\cline { 2 - 3 } Lactic acid bacteria & $8.4^{\mathrm{b}} \pm 0.3$ & $10.3^{\mathrm{a}} \pm 0.3$ & & $10.2^{\mathrm{a}} \pm 0.3$ & $5.4^{\mathrm{c}} \pm 0.2$ & 1.09 \\
Bifidobacteria & $7.58^{\mathrm{b}} \pm 0.3$ & $9.28^{\mathrm{a}} \pm 0.1$ & & $9.23^{\mathrm{a}} \pm 0.1$ & $5.18^{\mathrm{c}} \pm 0.1$ & 0.93 \\
Staphylococci & $2.78^{\mathrm{b}} \pm 0.2$ & $2.17^{\mathrm{c}} \pm 0.1$ & & $2.28^{\mathrm{bc}} \pm 0.1$ & $3.67^{\mathrm{a}} \pm 0.3$ & 0.57 \\
Coliforms & $2.80^{\mathrm{b}} \pm 0.2$ & $2.46^{\mathrm{b}} \pm 0.1$ & & $2.28^{\mathrm{b}} \pm 0.2$ & $3.69^{\mathrm{a}} \pm 0.4$ & 0.77 \\
\hline
\end{tabular}

* see foot note Table 1

\section{Conclusion}

Feeding bio-yoghurt fortified with glycomacropeptide, crude virgin olive oil and $B$. bifidum improve the growth parameters of rats and have a healthful effect on rats liver tissues and showed ahipolipidemic action demonstrated by a significant reduction in the concentration of plasma cholesterol, triglycerides and phospholipids and tended to lower plasma LDL cholesterol concentration which had harmful effects in the health and leading to lowering liver enzymes; GPT and GOT, moreover the rats fed on yoghurt fortified with GMP, CVOO and B. bifidum had higher counts of lactic acid bacteria and $B$. bifidum, and lower counts of staphylococci and coliforms more than control (-) group.

\section{REFERENCES}

Abbas, H.M.; Hassan, F.A.M.; Kassem, J. M.; Rasmy, N.M.; El-Kaluobi, M. H. and El-Okaby, M.F. (2015). Preparation of cheese yoghurt using extracted high virgin olive oil. Int. J. Dairy Sci., 10 (6): 288-296.

Alizadeh, A. and Ehsani, M.R. (2008). Probiotic survival in yoghurt made from ultrafiltered skim milk during refrigeration storage. Res. J. Biol. Sci., 3: 1163-1165.
American Public Health Association, (1992). Standard Method for the Examination of Dairy Products. $14^{\text {th }}$ Ed. Washington, USA.

AOAC (2016). Association of official Analytical Chemists. Official Methods of Analysis. $17^{\text {th }}$ Ed., Gaitherburg, M D, USA.

Brody, E.P. (2000). Biological activities of bovine glycomacropeptide. Br. J. Nutr., 84: 39-46.

Caramia, G.; Gori, A.; Valli, E. and Cerretani, L. (2012). Virgin olive oil in preventive medicine: From legend to epigenetics. Europ. J. Lipid Sci. and Technol., 114 (4): 375-388.

Chen, Q.; Cao, J.; Jia, Y.; Liu, X.; Yan, Y. and Pang, G. (2012). Modulation of mice fecal microbiota by administration of casein glycomacropeptide. Microbiol. Res., 3, e3.

Dave, R.I. and Shah, N.P. (1996). Evaluation of media for selective enumeration of Streptococcus thermopiles, Lactobacillus delbrueckii subsp. Bulgaricus, Lactobacillus acidophilus and bifidobacteria. J. Dairy Sci., 79: 1529.

De Man, J.C.; Rogosa, M. and Sharp, M. E. (1960). A medium for the cultivation of lactobacilli. J. Appl. Bacteriol., 23: 130-136. 
Estruch, R.; Ros, E.; Salas-Salvado, J.; Covas, M.I.; Corella, D. and Aros, F. (2013). Primary prevention of cardiovascular disease with a Mediterranean diet. The New England J. Med., 368 (14):1279-1290.

Farrell, H.M.Jr.; Jimenez-Flores, R.; Bleck, G.T.; Brown, E.M.; Butler, J.E.; Creamer, L.K.; Hicks, C.L., Hollar, C.M.; Ng-Kwai-Hang, K.F. and Swaisgood, H.E. (2004). Nomenclature of the proteins of cows' milk-Sixth revision. J. Dairy Sci., 87, 1641-1674.

Gandul-Rojas, B.; Cepero, M.R.L. and Minguez-Mosquera, M.I. (2000). Use of chlorophyll and carotenoid pigment composition to determine authenticity of virgin olive oil. J. Ame. Oil Chem. Soc., 77: 853-858.

Gorzynik-Debicka, M.; Przychodzen, P.; Cappello, F.; Kuban-Jankowska, A.; Marino Gammazza, A. and Knap, N. (2018). Potential health benefits of olive oil and plant polyphenols. Int. J. Molec. Sci., 19 (3): 686.

Gundogdu, E.; Çakmakçi, S. and Dagdemir, E. (2009). The effect of garlic (Allium sativum L.) on some quality properties and shelf-life of set and stirred yoghurt. Turkish J. Vet. and Anim. Sci., (33): 27-35.

Hargove, R. E. and Alford, J. A. (1978). Growth rate and feed efficiency of rats fed yoghurt and other fermented milk. J. Dairy Sci., 61:71.

Hualin Wanga, B.; Wat-Hung, S.; George Lim, T. and Jennifer M.F. W. (2014). Differential protective effects of extra virgin olive oil and corn oil in liver injury: A proteomic study. Food and Chem. Toxicol., 74:131-138.

Huang, C.J. and Fwu, M.L. (1992). Protien insufficiency aggravates the enhanced lipid peroxidation and reduced activities of antioxidative enzymes in rats fed diets high in polyunsaturated fat. J. Nutr., 122: 1182-1189.

Kawase, M.; Hashimoto, H.; Hosada, M.; Morita, H. and Hosono, A. (2000). Effect of administration of fermented milk containing whey protein concentrates to rats and healthy men on serum lipids and blood pressure. J. Dairy Sci., 83: 255.

Kheadr, E.E.; Abd El-Rahman, A.M. and El-Soukary, F.A. (2000). Impact of yoghurt and probiotic strains on strains on serum cholesterol and lipoprotein profile in rats. Alex. J. Agric. Res., 45: 81-100.

Marshall, K. (2004). Therapeutic applications of whey protein. Altern. Med. Rev., 9: 136-156.

Michael, B.; Yano, B.; Sellers, R.S.; R. Perry; Morton, D.; Roome, N.; Johnson, J.K. and Schafer, K. (2007). Evaluation of organ weights for rodent and non-rodent toxicity studies: A review of regulatory guidelines and a survey of current practices. Toxico. Patho., 35:742.

Misra, A.K. and Kulla, R.K. (1994). Use of Bifidobacteria bifidum for the manufacture of Bio-yoghurt and fruit Bio-yoghurt. Indian J. Dairy Sci., 47: 199.

Ney, D.M.; Gleason, S.T. and Van Calcar S.C. (2009). Nutritional management of PKU with glycomacropeptide from cheese whey. J. Inherit. Metab. Dis., 32: 32-39.

Ocakoglu, D.; Tokatli, F.; Ozen, B. and Korel, F. (2009). Distribution of simple phenols, phenolic acids and flavonoids in Turkish monovarietal extra virgin olive oils for two harvest years. Food Chem., 113: 401-410.

Othman, A.I. and El Missiry, M.A. (1998). Role of selenium against lead toxicity in male rat. J. Biochem. Mol. Tox., 12: 345. 
Patel, J.R.; Dave, J.M.; Dave, R.I. and Sannabhadti, S.S. (1992). Effect of feeding milk fermented with mixed culture of human strains of Lactobacilli on a faecal Lactobacilli and Coliform counts in human test subjects. Indian J. Dairy Sci., 45: 379-382.

Saarela, M.; Lahteenmaki, L.; Crittenden, R.; Salminen, $S$. and MattilaSandholm, T. (2002). Gut bacteria and health foods-the European perspective. Int. J. Food Microbiol., 78: 99-117.

Sahan, N.; Yasar, K. and Hayaloglu, A. A. (2008). Physical, chemical and flavor quality of non-fat yoghurt as affected by a $\beta$-glucan hydrocolloidal composite during storage. Food Hydrocolloid, 22, 1291:1297.

Sera, M.; Trujillo, J.A.; Guamis, B. and Ferragut, V. (2009). Flavour profiles and survival of starter cultures of yoghurt produced from high-pressure homogenized milk. Int. Dairy J., 19: 100-106.

Steel, R.; Torrie, J. and Dickey, D. (1997). Principles and Procedures of Statistics: A Biometrical Approach, $3^{\text {rd }}$ Ed., McGraw-Hill, New York, NY.

Sturgill, M.G. and Lambert, G.H. (1997). Xenobiotic-induced hepatotoxicity: mechanisms of liver injury and methods of monitoring hepatic function Clinical Chemistry, 43 (8): 1512-1526.

Tain, Q.; Wang, T.T.; Tang, X.; Hang, M.Z.; Leng, X.J. and Mao, X.Y. (2015). Developing a potential prebiotic of yoghurt: growth of Bifidobacterium and yoghurt cultures with addition of glycomacropeptide hydrolysate. Int. J. Food Sci. and Technol., 50: 120-127.

Tamime, A.Y. and Robinson, R.K. (1999). Yoghurt. Science and Technology. London, UK: Wood head Publishing.

Vinderola, C. G. and Reinheimer, J. A., 2000. Enumeration of Lactobacilii casei in the presence of $L$. acidophilus, Bifidobacteria and lactic starter bacteria in fermented dairy products. Int Dairy J., 10: $271-275$.

Wani, I.A. (2018). Olive oil and its principal bioactive compound: Hydroxytyrosol-A review of the recent literature. Trends in Food Sci. and Technol., 77: 77-90.

Yamani, M.I. and Ibrahim, S.A. (1996). The differential enumeration of lactobacillus delbruekii subspecies bulgaricus and Streptococcus salivarius subspecies thermopiles in yoghurt and labneh using an improved whey medium. J. Soc. Dairy Technol., 49: 103-108. 
الملخص العربي

\section{تأثير التغذية بزبادي حيوي مدعم بالجليكوماكروبيتيد وزيت الزيتون الخام البكر على الأنشطة البيولوجية للفئران}

\section{علا فتحى السيد1، هويدا عبدالله الثاذلى²، حسن عبدالمنعم الدمرداش1، ممدوح مصطفى كمال متولى 1}

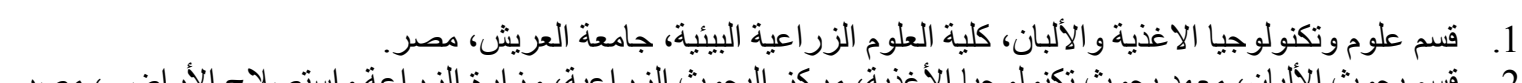

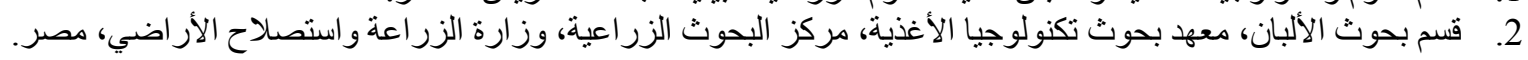
تم دراسة التأثيرات الغذائية والبيولوجية للزبادي المدعم ب (0,01\% جليكوماكروبيتيد، 0,1\% زيت الزيتون الخام

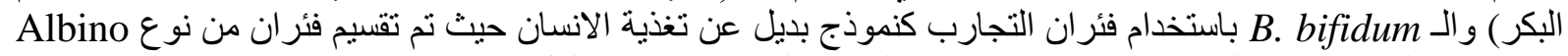

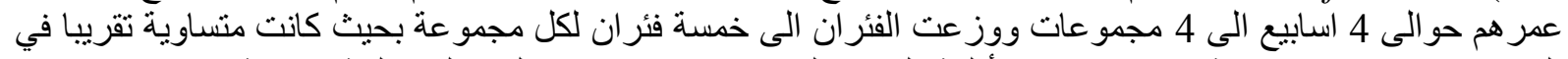
الوزن (بدون فروت معنوية احصائيا). وتم أقلمة الفئران لمدة اسبوع غذئيت خلئ خلالها على عليقة تجارية وبعد انتهاء فترة

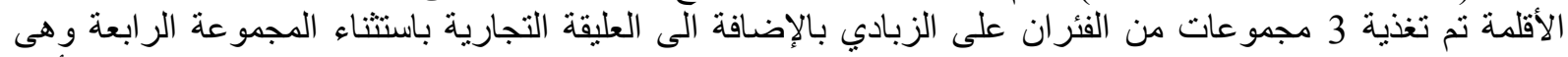

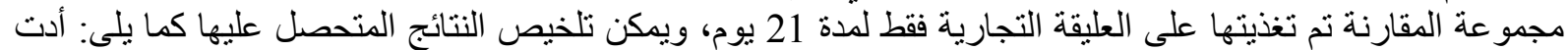

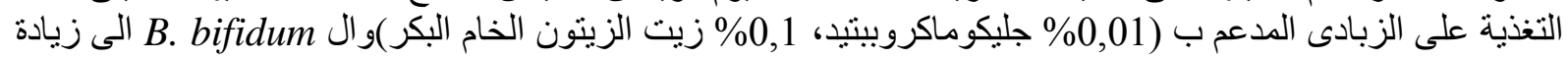

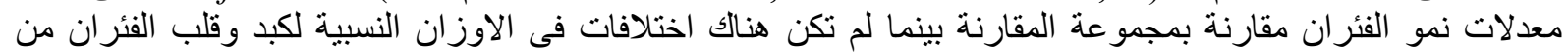

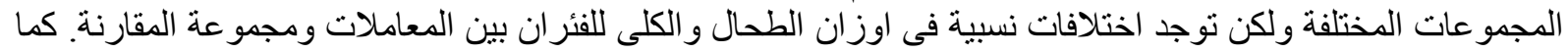

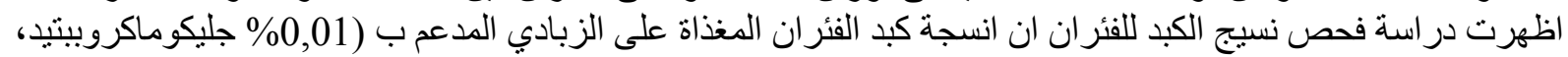

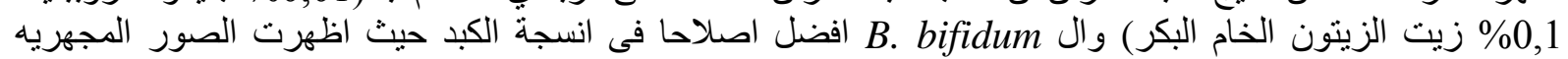

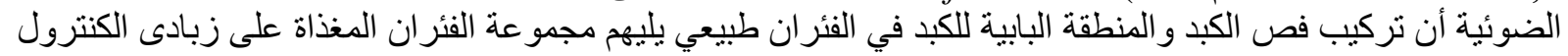

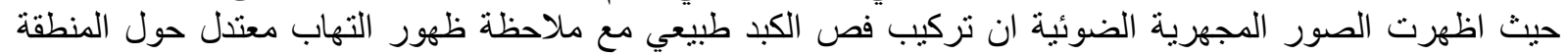

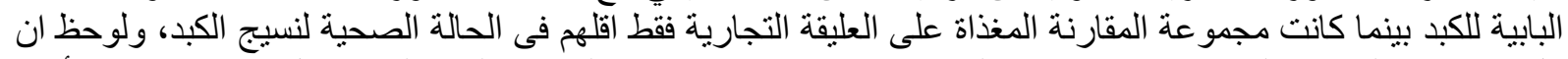

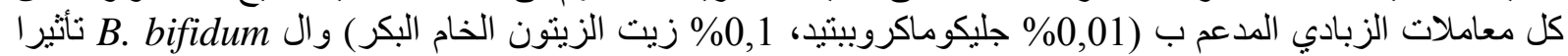

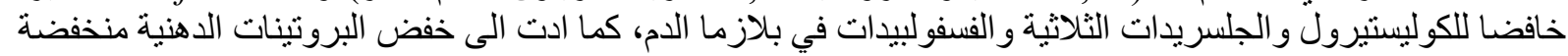

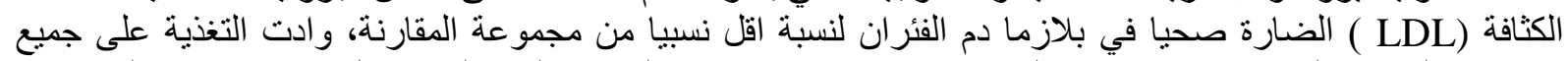

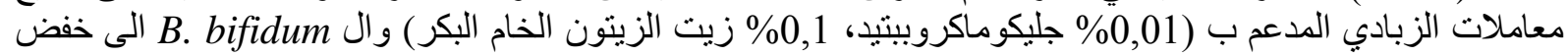

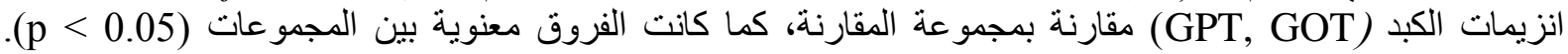

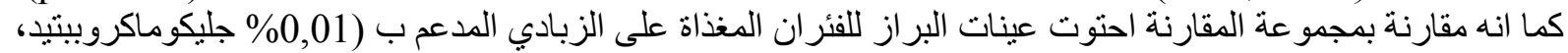

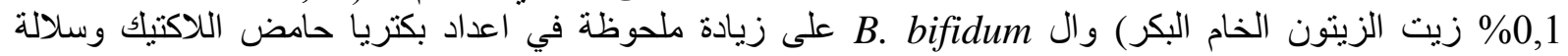
الـ B. bifidum ، بينما انخفضت الخداد البكر) واد بكتريا القولون و البكتريا العنقودية. الكلمات الاسترشادية: زبادي، B. bifidum، جليكوماكروبيتيد، زيت الزيتون.

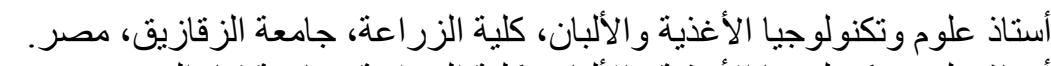

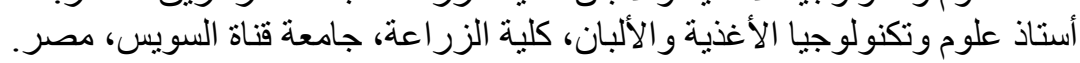

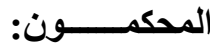

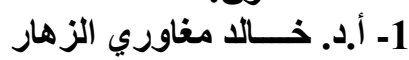
2- أ.د. رفيق عبدالرحمن محمد الزهار 
